\title{
The Numbered Treaties: \\ Similar Means to Dichotomous Ends
}

\section{Derek Whitehouse}

ABSTRACT: This essay reflects the recent trend among historians to assign an active role to both the Indians of the North-West Territories and the government during the Numbered Treaty process. The aboriginal peoples and the Canadian government entered the Treaty negociations hoping to achieve dichotomous ends. Concerned over white setelement and diminishing buffalo herds, the Indians sought to use the concessions granted them under the Treaties to ensure their cultural survival. The government, on the other hand, considered the Numbered Treaties a means of achieving the goal of their Indian policy, namely bringing about the assimilation of the Indian into EuroCanadian socicty.

On 2 August 1871, the Canadian government and the Indians of the North-West Territories signed the first of the Numbered Treaties. By the end of 1877 an additional six Treaties had been negotiated, effectively opening the NorthWest for settlement. Events leading up to the negotiations, and the negotiations themselves, provide clear evidence that a dichotomy existed between the goals that the Indians hoped to achieve through the Treaty process and those the government hoped to attain. The Indians,' realizing that their environment was changing, sought to protect their culture from threatening forces such as non-native agricultural settlement and diminishing buffalo herds. The government, meanwhile, strove to encourage the absorption of the Indian cultures into broader Euro-Canadian society, not only because it wanted to open the North-West for settlement, but also because it believed that assimilation was in the best interest of the Indian peoples. Despite the disparity in the objectives that each party sought, both considered the Treaties to be tools that were essential to achieving their goals. Thus, in the first seven Numbered Treaties, the government and the Indians employed similar means toward very dissimilar ends. 
Until recent decades, the historical analysis of Canada's past down-played or overlooked the contributions of aboriginal peoples. As James W. St.G. Walker noted of historical works such as Donald Creighton's Canada: The Heroic Beginnings, Indians were often presented as "not even minor actors in the Canadian drama, simply stage-props against which orhers work[ed] out their roles."

A case in point is the work of Allan Harper. In 1947, Harper wrote that, during the Numbered Treaty process, discussion was controlled by the government and "confined to a careful explanation of the terms, answering questions, firmly rejecting exorbitant demands, and dispelling false notions about the government's assumption of obligations." Similarly, in 1932, G. F. G. Stanley argued that the negotiation of the Treaties "was confined to an explanation of the terms" by the government and that "the Indians never understood what was happening." "Until the 1970s, historians portrayed Canada's aboriginal peoples as passive victims of dominant outside forces.

By the 1970s, however, historians were beginning to revise the image of the Indian peoples as victims. Fur trade historians like A. J. Ray spearheaded the revisionists' efforts. Writing in 1978, Ray argued that historical analyses which assumed "that the Indians were ruthlessly exploited and cheated in all areas and periods by white[s] ... gives us only half the story." A reinterpretation of Canada's past which recognized the contributions made by the Indian peoples would result in new perceptions of Indians as active and creative agents in the historical process. Ray realized that treating the largely ignored aboriginal peoples as active participants in Canada's past was essential to the appropriate placement of the Indian in the historical record."

While the process of reinterpreting Canada's past began with fur trade historians such as A. J. Ray and Donald B. Freeman, ${ }^{7}$ historians working in other fields also reassessed the Indian perspective. Sylvia Van Kirk, for example, argued that the fur trade "was not simply an economic activity, but a social and cultural complex." Consequently, when 
examining the role that Indian, Métis, and white women had in the fur trade, Van Kirk asserted that the "examination of the role played by women as actors upon the fur trade stage is essential to a full understanding of the complexities" of early Western Canadian society. 'Thus, in viewing Canada's aboriginal peoples as active agents of history, historians developed new interpretations of economic, social, religious, and political interactions between white and Indian. ${ }^{10}$

J. R. Miller noted, however, that most efforts of historians to restore the Canadian aboriginal to the position of an active historical agent have focused upon the period preceding the 1860s. Indeed, as late as 1990, Miller argued that "studies of Indian-white relations after Confederation ... have thus far largely proved resistant to reinterpretation." "I Articles by Jean Friesen, D. J. Hall, and John Leonard Taylor, however, are notable exceptions in that they demonstrate that the revisionists are no longer emphasizing the pre-Confederation period. Taylor, for example, maintained that the Numbered Treaties were the product of Indian and government interactions, and not, as Harper had argued, the result of the government dictating terms that the Indians had either to "accept or reject."12 Taylor understood the Treaty process as having been an open negotiation in which the Indians introduced innovations that the government was subsequently forced to accept. If the government had not accepted the innovations, it "would have had even more difficulty getting the treaties, if [it] had been able to get them at all." ${ }^{3}$

Duncan Campbell Scote, Canada's Deputy Superintendent General of Indian Affairs from 1913 to 1932, attested to the underlying continuity of the government's Indian policy some thirty years after the completion of the first seven Numbered Treaties. In 1909. Scott stated that "the true and uniform policy [of the government] ... has made the Canadian Indian believe the British sovereign is his great parent and [he] himself is a child under beneficent protection." 14 He went on to say that "the happiest future for the Indian race is ... absorption into the 
general population, and this is the object of the policy of our government." ${ }^{\text {Is }}$ Toward this goal, the government believed that

agriculture, education, and religion would, in time, provide the Indian with far more than he had lost. Eventually the settlement of the West would uplift the native from his state [of savagery or barbarism]. ${ }^{16}$

The Canadian government genuinely believed that its goal of assimilation was in the best interest of the Indian peoples. The Numbered Treaties were intended to provide the tools which goverument officials thought were necessary to facilitate this assimilation: reserve agriculture, schools, and missionaries. ${ }^{17}$

Much of the Canadian population shared the government's desire to absorb the Indian peoples into broader Euro-Canadian society. For decades, official documents and reports, and "the works of scientists, social scientists, travellers, humanitarians, and missionaries" 18 had served to shape the perception that assimilation was not only in the best interest of the Canadian population, but also of the aboriginal peoples themselves. As a result of these varied influences, a paternalistic approach to the assimilation of the Indians was seen as both "desirable ... and necessary. With the Indian as the ward of the state, steps could be taken to protect him from the harmful effects of white culture while teaching him its benefits."

Imperialistic influences also strengthened and confirmed the idea that the assimilation of the Indian was the true and correct policy to follow. Colonies within the British Empire, historian Walter Houghton argued, had been founded

it was said-and believed-by the generous and altruistic desire of spreading throughout the habitable globe all the characteristics of 
Englishmen-their encrgy, their civilization, their religion and their freedom. ${ }^{23}$

Consequently, those directing the government's Indian policy saw themselves as fulfilling this aspect of Britain's destiny. What could be better for an improvident, intemperate, and latently indolent people who were prone to privation $^{21}$ than to become active members of a nation destined to assume the role of dominance in the British Empire? The government expected that agriculture would help the Indians overcome the inherent weaknesses that it believed they shared as peoples, and thus it would aid their eventual assimilation into Canadian society. The aboriginal peoples would then become part of that which "represent[ed] man's highest achievement in the development of governmental and social institutions."22 In order for the Indians to be assimilated, however, the government knew that the cultural identity of the Canadian aboriginals would have to be eliminated. On a cultural level, the Indian would have to adopt the traditions and practices of the white man. ${ }^{2.3}$

In 1877, the prominent American anthropologist Lewis Henry Morgan put to print a theory, the essence of which many of his era were already familiar with. Morgan asserted that all societies passed through the stages of savagery and barbarism on their way to becoming civilized. ${ }^{24}$ Consequently, because passage from one level of development to the next was thought to be unilinear, "each step ... was regarded as essential to the next and [thus] could not be transcended." ${ }^{25}$ According to the unilinear evolutionists' argument, it followed that because many of the Indian bands in the North-West engaged in hunting and gathering subsistence, they were in the initial, savage phase of the evolutionary path. Subscribing to Morgan's theory, the government believed that the Indians would have to pass through barbarism, a stage which was characterized by domestication and cultivation, before they could become civilized. Reserve agriculture was, therefore, to be the Indian peoples' "place of probation, a training ground in the lessons of civilization and cirizenship." 26 
Besides viewing the Treaties as a means to encourage the assimilation of the Indian, government officials also intended to use the Treaties to open the North-West for settlement in accordance with its national policy. ${ }^{27}$ The Royal Proclamation of 1763 made it illegal for anyone, save the Crown, to purchase land in "Indian Country." ${ }^{28}$ Although this provision "did not apply to the Hudson's Bay Company lands, [it did] set out the basis" by which these lands would be settled after their transfer to Canada in $1870 .{ }^{29}$ It was necessary, therefore, for the government to extinguish Indian citle to land in the North-West before settlement could begin. Alexander Morris, the lieutenant governor of the North-West Territories from 1872 to 1876 , summarized this objective during the discussions concerning Treaty One and Treaty Two. According to Morris,

it was desirable to secure the extinction of the Indian title not only to the lands within Manitoba, but also to so much of the rimber grounds cast and north of the Province as were required for immediate entry and use, also of a large tract of cultivate ground west of the Portage, where there were very few Indian inhabitants. ${ }^{30}$

Regarding the complecion of Treaty Three, he continued:

and so was closed, a treaty, wherehy a territory was enabled to beopened up, of great importance to Canada, embracing as it does the lacific Railway route to the North West Territoriesa wide extent of fertile lands, and, as is believed, great mineral resources. ${ }^{31}$

Extinguishing Indian title to land in the North-West so that settlement could commence thus constituted the second goal of the government's Treaty policy.

Morris' words demonstrate that pressures on land, resulting from the government's settlement policy, were the primary motivators behind the government's decision to 
treat. That settlement pressures were of such great import to the Canadian government can be largely attributed to the fact that, with an annual federal budget of only $\$ 19$ million and with the construction of a transcontinental railway a national preoccupation, the government was seeking to devote only as many resources as were necessary to negotiating treaties with the Indians. ${ }^{32}$ Indeed, Joseph Howe, Secretary of State for the Provinces cautioned Treaty Commissioner Wemyss Simpson to

endeavour to sceure the session [sic] of the lands upon terms as favourable as possible to the Government, not going as far as the maximum sum hereafter named unless it be found impossible to obtain theobject for a less amount. ${ }^{3.3}$

In addition, Prime Minister Alexander Mackenzie pointed out that, when compared to "other countries," Canada's Treacy policy was not only "a humane, just, and Christian policy," it was also "the cheapest." 34 Only when it was so required by settlement pressures, therefore, would the government be induced to negotiate.

The requests of the Indian peoples themselves had little impact on the timing of negotiations when settlement pressures were not at issue. Indeed, some of the bands who would eventually be included under Treaty Six had requested negotiations toward an agreement a full five years before actual proceedings began. The government, however, did little to address the "[general] feeling of discontent and uneasiness," arising from the fact that they had not been treated with, "[that] prevailed ... amongst the Assiniboines and Crees." 35 Only when the Indians threatened to disrupt survey and telegraph crews was the government finally compelled to negotiate. ${ }^{36}$

Settlement pressure of a different type was the key factor in the government's movement to negotiate Treaty Seven. On this occasion, it was white settlers who pressured the government for an agreement in order to allay growing 
concerns regarding their own safery. Father Constantine Scollen noted that

The Blackfeet are extremely jealous of what they consider their country and have never allowed any white men. Half-breeds, or Crees to remain in it for any length of time... [As such, the settlers] are anxious that a treaty be made as soon as pussible, so that they may know what portions of land they can hold without fear of being molested. ${ }^{37}$

Consequently, it was again in the government's interest to obcain a treaty, despite the fact that, unofficially at least, the Blackfoot were not seeking such an agreement.

Humanistic, expansionistic, imperialistic, and nationalistic beliefs, values, and ideas thus shaped the Canadian government's Indian policy. Furthermore, it is clear that the government engaged in the treaty-making process for two main reasons. First, negotiations were initiated to facilitate the Euro-Canadian agricultural settlement of the North-West. Second, the Treaty concessions provided the means by which the distinctiveness, uniqueness, and heritage of the Indian could be eliminated, and what was left could be absorbed into the Euro-Canadian culture.

For the Indians, however, the Treaties served an entirely different function. Aware that the Treaties would open the North-West up for rapid settlement, the aboriginal peoples also understood that settlement was inevitable, with or without the Treaties. Consequently, the Indians sought to use the concessions that they gained under the Treaty system to ensure that their culture would survive, an end antithetical to that being sought by the government. To achieve their goal, the Indians, much like the government, expressed an interest in schools and in missionaries and "were desirous of according to the wish of their great Mother" that they "discard their former precarious mode of living and adopt the agricultural pursuits of the white 
man." ${ }^{38}$ Aware that social and economic pressures were making it inevitable that their way of life was coming to an end, the aboriginal peoples sought to adopt a new way of life, one which would allow them to retain their independent cultures.

The Ojibwa and the Swampy Cree, who were among the first Indian peoples to be involved in the Numbered Treary process, had ourwardly expressed concern regarding the "influx of population" onto theirlands. Indeed, Alexander Morris noted that "the Indians in Manitoba ... had in some instances obstructed settlers and surveyors" 39 until their calls for a Treaty were met. Thus, while governmental policy dictated that Treaties were to be negotiated only when so required by settlement pressures, the Indian peoples were still able to "[rush] the government's timetable somewhat." 40

Concerns about the influx of white settlers also affected the tribes involved in later negotiations. The Plains Cree were aware that great numbers of white settlers would soon be entering their lands. During Treaty Six negotiations, Star Blanket, the Chief of the Wood Indians, cautioned those of his people who opposed the Treaty:

[When the buffalo are gone] what then will be left us with which to bargain? With the buffalo gone we will have only the vacant prairie which none of us have learned to use. Can we stop the power of the white man from spreading over the land like the grasshoppers that cloud the sky and then fall to consume every blade of grass and every leaf on the trees in their path? I think not. Before this happens, let us ponder carefully our choice of roads. ${ }^{41}$

Indeed, in 1875, the Reverend George McDougall had been informed by certain Cree that "they were unanimous in their determination to oppose the running of lines, or the making of roads through their country, until an agreement between the Government and them had been effected." 42 This concern was echoed by the Plains Assiniboine who, on 
hearing that they would be treated with, informed Alexander Morris that "foolish men have told us that the Great Chief would send his young men to our country until they outnumbered us, and that then he would laugh at us." 13

The Blackfoot, who in 1877 were signatories to Treary Seven, also saw the early signs of white settlement. Unlike many of the tribes further east, however, they themselves were not seeking a Treaty. It is likely, nevertheless, that factors such as the diminishing buffalo herds and the steady increase of white settlers into their region would have eventually "disposed the Blackfoot towards making a treary." 44 Indeed, the likes of the Reverends George and John McDougall and Fathers Scollen and Fourmond had penetrated as far south as the Bow River by 1877. This fact "not only indicates the hold the missionaries were gaining on the prairie Indians but also how much the Blackfoot hold on their native land was slipping." ${ }^{45}$

The Black foot's concern over the diminishing buffalo herds had also been voiced by the orher Plains tribes who had realized, at least as early as the 1850s, that the herds were becoming more scarce. ${ }^{46}$ From that time on, the Cree, for example, had attempred to protect the herds by calling on the government to limit the hunting of these creatures to Indians alone. ${ }^{47}$ Yet, it was not until 1876 that "the NorthWest Council [considered] the framing of a law to protect the buffaloes." 48 Nothing ever came of the Council's consideration, however, and less than three years later the buffalo had disappeared from Canada.

Despite attempts to protect the buffalo, the Cree had largely accepted the fact that their way of life was coming to an end. Star Blanket addressed this concern when he said:

We have always lived and received our needs in clothing, shelter, and food from the countless multitudes of buffalo that have been with us since the earliest memory of our people. No one with open eyes and open minds can doubt that the buffalo will soon be a thing of the past. Will 
pass? No! They will die and become just a memory unless we find another way.... The mother earth has always given us plenty with the grass that fed the buffalo. Surely we can learn the ways that made the whiteman strong."

Thus, Canada's aboriginal peoples realized that an adaptation to a new way of life was required, and, like the government, most saw agriculture as the answer.

Many Canadians were likely surprised to learn that the Indians were willing to take up cultivating the soil. Most Euro-Canadians believed that Indians resisted change and had lived in their current state for untold centuries. The Methodist missionary John MacLean described Canadian efforts to "civilize" and "uplift" the Indian peoples:

We wish to make them white men, and they desire to become better Indians. They helieve the native culture is best suited for themselves, and having developed under it, and enjoyed it so long, they care not to give it up for an untried system. ${ }^{\text {so }}$

The missionary John McDougall, who in 1876 was a commissioner for the government's treaty negotiations, concurred. He wrote that the

aboriginal man with his traditions unchanged chrough the centuries met face to face representatives of another old but ever-changing race to negotiate in peace and friendship their future negotiations in this new land."1

Much of the Euro-Canadian populace thus believed that the culcures of the Indian peoples were static.

The perception that the Indian way of life was unchanging proved to be unfounded, however. In the two centuries prior to the signing of the Numbered Treaties, many aboriginal peoples had adapted to the new economies that had been created by the fur trade. That the Indians 
that had been created by the fur trade. That the Indians understood the concepts of dynamic economies is evident when one examines the adaptability of the Plains Cree. Prior to European contact, the Cree were primarily woodland hunters and gatherers. ${ }^{52}$ After 1670 , however, they had assumed a middleman role in the fur trade. When the fur traders themselves began to move into the interior, thus effectively bypassing them, the Cree had adapted again by moving on to the Plains and becoming buffalo hunters. ${ }^{53}$ Although they were perhaps caught off guard by the rapidity with which they were required to adapt, ${ }^{54}$ the Indian peoples accepted the fact that their lifestyle would have to change again. What the aboriginals were concerned with, however, was the impact that this change would have on their culture.

The desire of Beardy, the Chief of the Willow Crees, to negotiate in a place that "had been revealed to him in a vision" 5 provides clear evidence that the Indians believed the Treaties to be an important means of preserving Native culture. In Cree culture, as in almost all Plains cultures, the dream or vision was of great significance. The Plains Indian perceived dreams to be sources of powerful knowledge and insight. As scholar Joseph Epes Brown argued, the "nature of the received vision often obligate[d] the recipient to externalize the experience and thus ... share the power with the larger community." "5o To ensure that the Treaty would be negotiated successfully and that his people would achieve what they desired from these proceedings, Beardy sought to re-enact his vision. The government negotiators, however, misunderstood his intentions and assumed that Beardy was merely being difficult. Consequently, the government negotiators would only treat with the Willow Crees at the location they themselves had designated. ${ }^{77}$

The Indians of Treaty Six ${ }^{58}$ realized that, in order to protect their culture from being destroyed by the inevitable incursion of white settlers onto their lands, they had to reach an agreement with the government. As a result, they took an active role in the Treaty negotiations. Entering the talks, the 
government was prepared to offer essentially the same concessions that had been granted under the first five Treaties. Regarding Treaty One, the government had intended only to escablish reserves and grant annuities in exchange for the surrender of Indian title to their lands. The Indians, however, eventually extracted additional concessions such as the provision of agricultural and educational assistance. ${ }^{59}$ Similarly, the Indian signatories to Treaty Three were able ro obtain further allowances from the government including an increase in the allotment of land from 100 acres for each family of five to 640 acres and an increase in annuities from $\$ 3$ to $\$ 5 . .^{60}$

The government had acceded to the Indians' demands as they were consistent with their goals of assimilation. For the Indian peoples to be able to cultivate those reserve lands that were to be set aside for them, they had to be provided with the implements and the knowledge necessary to undertake such a rask. As Henry Prince, Chief of the St. Peter's band, asked when he was informed that the government wanted the Indians to take up agriculture but would provide them with only land and annuities, "[How could] the Queen expect the Indian to cultivate the land? 'They cannot scratch it - work it with their fingers. What assistance will they get if they settle down?"'ol Wemyss Simpson apparently concurred when he wrote that the aforementioned concessions were given "with a view to inducing the Indians to adopt the habits and labours of civilization." 62

Those concessions which were granted under Treaties One through Five, however, did not fully address the apprehensions that the Plains Cree had concerning the protection of their culture. Consequently, much like the Saulteaux of Treary One, the Cree were able to demand and receive additions to the Treary which the government had not originally intended to grant. ${ }^{63}$ These new concessions, namely the granting of $\$ 1000$ a year for three years, the medicine chest clause, and the pestilence/famine clause, 
addressed the concerns of the Plains Cree regarding their adaptation to, and survival in, their new environment. ${ }^{.64}$

The government agreed to pay a sum of $\$ 1000$ to those bands who were "settled on the reserves and [who were] engaged in cultivating the soil."'s. Consequently, only those Indians who were already considered to be in the process of becoming civilized were to receive benefits from the clause. The government therefore regarded the $\$ 1000$ as furcher contributing to the eventual assimilation of the Indian and achieving the ultimate goal of its Indian policy.

The monetary concession itself had been made in response to Cree demands for "food in the spring" when they began to farm." In the spring, and especially during the initial years of cultivation, great expenditures of time and energy would have to be made in ploughing, seeding, and cultivating the land. Consequently, the Indians would have to abandon non-agricultural means of acquiring sustenance, such as hunting, gathering, and trapping, to ensure that their agricultural efforts were as successful as possible. The Indians believed that a secure source of food would assist them in their adaption to reserve agriculture and thus help them to preserve a unique and separate identity in EuroCanadian society.

With regard to the pestilence/famine clause and the medicine chest clause, both were applicable only to those Indians who had signed Treaty Six ${ }^{67}$ Again, the government considered these concessions as aiding the inevitable assimilation of the Plains Cree as they addressed specific concerns that the $\mathrm{Cree}$ had expressed. Alexander Morris was aware that "small-pox had destroyed [the Plains Cree] by hundreds a few years before" $6 \mathrm{~s}$ and that epidemics of scarlet fever and measles had also recently affected the region. In addition, the fact that the buffalo herds were rapidly disappearing had raised concerns about starvation at a time when adaption to a new method of subsistence, namely agriculture, was required.".9 In the words of Morris, the Indians "dreaded pestilence and famine." ${ }^{" 70}$ The government regarded sustenance requirements as being specific to the 
Plains Cree alone, however. Indeed, with the exception of "spring provisions for several years" as provided in Treaty Eight, these "pestilence/famine concessions," or any that were similar, were not repeated in subsequent agreements. ${ }^{11}$

The Indians viewed the pestilence/famine clause as a means of insuring themselves against any hardships that they might have encountered during their initial attempts to cultivate their reserve lands including both crop failure and destruction. ${ }^{72}$ Big Child, Chief of the Carlton Indians, noted:

It is well known that if we have plenty in our gardens and crops we would not insist on gerting more provisions, but it is only in the case of extremity and from the ignorance of Indians in commencing to work the land that we speak. We are in the dark. This is no trivial matter with us. $^{3}$

Knowing that the buffalo would soon be gone and that agriculture was to become their main means of support, the Indians were acutely aware of the dangers that could arise if they proved slow to learn proper agricultural techniques or if some disaster befell them. If either situation were to occur without the protection and assistance of the government, the Indians knew that they would starve.

The medicine chest clause addressed specific concerns held by the Cree regarding the aforementioned epidemics that had recently swept through the Plains. As a result of smallpox alone, hundreds of Plains Cree had died and many more had become seriously ill by the early 1870 s. In one band alone, over fifty individuals had perished. ${ }^{74}$ To make matters worse, during times of affliction many hunters and trappers were either killed or incapacicated to the point where they were unable to perform everyday duties. As a result, starvation and economic difficulties (the latter exacerbated by the need to destroy the property of those who had been infected) often accompanied and outlasted the 
epidemics. The Indians were aware that a vaccine to combat the disease did exist, but it was not readily available to them. ${ }^{75}$ Thus, the aboriginal peoples believed that having a medicine chest on each reserve would help to ensure that both unnecessary deaths and economic hardships resulting from illnesses were minimized.

A consideration of the roles of both the Indian peoples and the Canadian government in the Numbered Treaty process, reveals that both parties sought similar terms to achieve dichotomous ends. While both the Indians and the Canadian government supported the concept of reserve agriculture as outlined in the Treaties, each saw cultivation as a way to help achieve different goals. The Indians recognized that their environment was changing and considered reserve agriculture to be the best method of adapting to a new way of life. In making this transition, however, the Indians attempted to protect their people from being assimilated into white sociery, thus preserving their separate identities. The government, on the other hand, saw both the Treaties and reserve agriculture as the most practical way to achieve the goals of its Indian policy. By utilizing the Treaties to open up the North-West for settlement, the government hoped to bring about that which it considered to be in the best interest of the Indian peoples: their assimilation into white society. 


\section{NOTES}

'It should be noted that many different groups of Indians were involved in the Numbered Treaty process, including various bands of Ojibwa, Cree, Assiniboine, and Blackfoot. For a brief introduction to the firse seven of the Numbered Treaties, refer to Gerald Friesen, The Canadian Prairies: A History (Toronto, 1987),138-146.

'James W. St.G. Walker, "The Indian in Canadian Historical Writing. 1972-1982" in Jan A. L. Getty and Antoine S. Lussier, eds.. As Long as the Sun Shines and the Water Flows: A Reader in Canadian Native Studies, (Vancouver, 1983), 346. Reprinted from Canadian Historical Associacion Historical Papers (1971), 21-47.

'Allan G. Harper, "Canada's Indian Administration: The Treaty System," America Indigena 7,2 (April, 1947), 145

"G.F.G. Stanley, "The Indian Background of Canadian History" in Canadian Historical Association Report (1932), 20. Quoted in Jean Friesen, "Magnificent Gifts: The Treaties of Canada with the Indians of the Northwest 1869-76." Transactions of the Royal Society of Canada, Fifth Series, 1, (1962), 42.

'Arthur J. Ray. "Fur Trade History as an Aspect of Native History" in R. Douglas Francis and Donald B. Smith, eds., Readings in Canadian History (Pre-Confederation) (Toronto, 1982), 151

'Ibid., 149-151

'See A. J. Ray, Indians in the Fur Trade 1660-1870(Toronto, 1974) and A. J. Ray and Donald B. Freeman Give us Good Measure: An Economic Analysis of Relations Between the Indians and the Hudson's Bay Company Before 1763 (Toronto, 1978).

${ }^{8}$ Sylvia Van Kirk, Many Tender Ties: Women in Fur-Trade Society, 1670-1870 (Winnipeg. 1980), 2

'lbid., 8

${ }^{10}$ D.J. Hall, "A Serene Atmosphere"? Treaty I Revisited." Canadian Journal of Native Studies 4,2 (1984), 322. Also note works such as J.R. Miller. Skyscrapers Hide the Heavens: A History of Indian-White Relations in Canada, rev. ed. (Toronto, 1991) and John Webster Grant, Moon of Wintertime: Missionaries and the Indians of Canada in Encounter since 1534 (Toronto, 1984).

"J. R. Miller, "Owen Glendower, Hotspur, and Canadian Indian Policy," Ethnahistory 37. (Fall, 1990), 388

'Harper, "Canada's Indian Administration," 145

"John Leonard 'Taylor, "Canada's Northwest Indian Policy in the 1870s: Traditional Premises and Necessary Innovations" in Richard Price, ed., The Spirit of the Albertn Indian Trenties, (Montreal, 1980), 6. Also see Friesen, "Magnificent Gifts" and Hall, "Serene Atmosphere." 
'"John Leonard Taylor, "Canada's Northwest Indian Policy in the 1870s: Traditional Premises and Necessary Innovations" in Richard Price, cd., The Spirit of the Alberta Indian Treaties, (Monereal, 1980), 6. Also see Friesen, "Magnificent Gifts" and Hall, "Serenc Atmosphere." ${ }^{14}$ Brian E. Titley, A Narrow Vision: Duncan Campbell Scott and the Administration of Indian Affairs in Canada (Vancouver. 1986), 27. For an analysis of the government's Indian strategy prior to the Indian Act and how their post-Confederation goals could be considered to be an extension of a somewhat continuous policy, refer to John E. Leslic and Ron Maguire, The Historical Development of the Indian Act (Ottawa, 1978).

'Ihid., 34

16.Doug Owram, Promise of Eden: The Canadian Expansionist Movement and the Idea of the West 1856-1900 (Toronto, 1981), 132 "It should be noted that although missions were outside the purview of the government, both the government and the Indians wished to see them established on reserves. As such, although not prescribed by the Treaties themselves, the establishment of missions was integral to the objectives of both the Indians and the government.

${ }^{18}$ L.F.S. Upton. "The Origins of Canadian Indian Policy," Joumal of Canadian Studies 8,4 (1973), 5. Also see Grant, Moon of Wintertime. 85.

19 Owram, Promise of Eden, 132

${ }^{20}$ Walter E. Houghton, The Victorian Frame of Mind: 1830-1870 (New Haven, 1957), 47

${ }^{21}$ Marcel Giraud, The Mitis in the Canadian West Vol. I trans. George Woodcock, (Lincoln. 1986), 349-351

${ }^{22}$ Owram, Promise of Eden, 126

"John MacLean, Indians of Canada: Manners and Customs (Toronto. 1889), 263

${ }^{24}$ Abraham Rosman and Paula G. Rubel, Tapestry of Culture, 2nd ed. (New York. 1985), 14. See also Lewis Henry Morgan. "Ancient Society" in Paul Bohannan and Mark Cilazer. eds., High Points in Anthropology (New York. 1973), 30-60. Morgan's theory concerning the evolutionary development of societies was an embodiment of Social Darwinism, a theory that held that societal evolution represented progress. Historian. Laurence S. Fallis Jr.. noted of intellectual thought in mid-to-late nineteenth-century Canada that the "idea of progress by making change appear to be natural, if not inevitable, made change acceptable." Laurence S. Fiallis Jr., "The Idea of Progress in the Province of Canada: A Study in the History of Ideas" in W. L. Morton, ed., The Shield of Achilles: Aspects of Canada in the Victorian Age (Toronto, 1968), 173. The "cultural advancement" of the Indian peoples was thus held by much of the Euro-Canadian population as being in the best interest of all concerned. particularly with regard to the Indians. 
26Ibid., 19. See also Carter, Lost Harvests, $36-45$ where it is noted that some Indian peoples possessed agricultural experience that pre-dated the Treaty era. Indeed. Carter notes that in "nineteenth-century Manitoba before the treaties of the $1870 \mathrm{~s}$. Indian participation in gardening and farming was not uncommon." Ihid., 40

${ }^{27}$ Friesen. The Canadian Prairies, 184-186

${ }^{23}$ Leslie. The Historical Development, 3-5

${ }^{2}$ Richard C. Daniel, A History of Native Claims in Canada: $1867-$ 1979 (Ottawa, 1979), 2. As Daniel noted, the terms of the purchase agreement effectively extended the terms of the Royal Proclamation to the newly acquired North-West. Article 14 of the Imperial Order in Council that gave effect to the transfer stated that "[a]ny claims of the Indians to compensation for lands shall be disposed of by the Canadian government in communication with the Imperial Government; and that the Company shall be relieved of all responsibility in respect to them." Ibid., 1-2

${ }^{30}$ Alexander Morris, The Treaties of Canada with the Indians of Manitoba and the North-West Territories, 1880 (Toronto, reprint. 1971), 26. Morris was the chief negotiator for the crown during the negotiations of Treaties Three, Four, Five, and Six. He also revised Treaties One and Two. Jean Friesen, "Alexander Morris" in Francess G. Halpenny, ed., Dictionary of Canadian Biography 11, (Toronto, 1982), 612.

"Ibid., 46

${ }^{32}$ Miller, Skyscrapers Hide the Heavens, 162. See also Gerald Friesen, The Canadian Prairies, 177-8 regarding the funding that the government supplied for the construction of the C.P.R. including "direct grants of $\$ 25$ million." Also note Carter, Lost Harvests, 22.

"As quoted in Daniel, $A$ History of Native Claims, 6.

"As quoted in Miller, Skyscrapers Hide the Heavens, 162.

"Morris, The Treaties of Canada, 171

36 Ibid., 172

${ }^{3}$ Ibid., 249

${ }^{38}$ Ibid., 40

${ }^{39}$ Ibid., 25-26

${ }^{40}$ Hall, "A Serene Atmosphere," 323. Also see John Tobias, "Canada's Subjugation of the Plains Cree," Canadian Historical Review 44.4 (1983), 519.548. Tobias provides an alternate view to that of Hall. While Hall qualifies his remark with the term "somewhat," Tobias down-plays the government's role, at least with regards to Treaty One. I would argue that until settlement became a governmental priority. the Indians were able to do little to make their demands carry much weight. This is evident in the five-year interval between when the Plains Cree expressed a desire to 
treat and the beginning of negotiations. Again, in the above case. the government acted only when it perceived that its plans regarding setelement mighe be threatened.

${ }^{41}$ Peter Erasmus, Buffalo Days and Nights (Calgary, 1976), 249. Historian Olive Patricia Dickason makes note of the English spelling of Star Blanket's true Indian name, Ahchacoosacootacoopits, in Canada's First Nations: A Histnryof Founding Peoples from Earliest Times(Toronto, 1992), 300. Similarly. Alexander Morris noted the spelling of Star Blanket's name as Ah-tak-ah-coop in The Treaties of Canada, 213.

${ }^{12}$ Morris, The Treaties of Canada, 173

43. [bid., 174

"John Leonard Taylor, "Two Views on the Meaning of Treaties Six and Seven," in Richard Price, ed., The Spirit of the Alberta Indian Trenties (Montreal, 1980), 26

15James MacGregor, Father Lacombe (Edmonton, 1978), 233

*Carter, Lost Hartuests, 35-36

1Tohias, "Canada's Subjugation of the Plains Crec," 106

${ }^{48}$ Morris, The Treaties of Canada, 241

${ }^{49}$ Erasmus, Buffalo Days and Nights, 250

soJohn MacLean, Canadian Savage Folk: The Native Tribes of Canada (Toronto, 1896), 543

"John McDougall, Opening the Great West: Experiences of a Missionary in 1875-76 (Calgary, 1970). 58

"It should be noted that there is a historical debate concerning the western extent of the Cree horders. John S. Milloy argued for the traditionally accepted interpretation that the Cree "adopted a plains way of life in the 1790s" in The Plains Cree: Trade. Diplomacy and War. 1790 to 1870 (Winnipeg, 1988), xiv. According to Milloy, the Plains Cree became "clearly identifiable" when they "own[ed] horses" and had "a different relationship to the buffalo herds and to the Europeans" than their Woodland Cree ancestors. Ibid., 23-26. Milloy, argued that the Plains Cree's "transition from beaver to buffalo, from forest to plain. was completed" during the 1790s. Ibid.. 27. Dale Russell, however. reinterpreted the archival and secondary resources and contended that the Cree of the mid-1700s did not shift "from the forests to the grasslands. Rather, they were then, and continued to be, a parkland group." Dale Russell, Eighteenth-Century Western Cres and their Neighbours (Hull, 1991), 218. Russell helieved that the western limits of the Cree had been placed 800 kilometres too far east by previous scholars (lbid., 212) and that the change in the role of middleman Cree to Plains Cree was gradual and somewhat minimal as they already possessed experience at living in a Parkland environment.

"Tobias, "Canada's Subjugation of the Plains Cree," 105

"MacGrcgor, Father Lacombe, 231

"Morris, The Treaties of Canada, 176 
${ }^{56}$ Joseph Epes Brown. The Spiritual Legacy of the American Indian (New York, 1992), 15

"Morris. The Treaties of Canada. 176. See also Ibid., 225.

"Tobias, "Canada's Subjugation of the Plains Cree," 106-107. It is important to note that not all members of the Plains Cree considered the final text of Treaty Six to be adequate for ensuring the protection of their culcure. Big Bear and little Pine did not sign the Treaty as they believed it would result in a "loss of autonomy" for their people and result in their being "enslave[d]."

${ }^{59} \mathrm{Hall}$, "A Serene Atmosphere," 327-331. These concessions took the form of outside promises which were not adhered to by the government until 1875. That the government was willing to agree to these concessions is evident in that Treaty 3, signed in 1873, contained distinctly similar provisals.

${ }^{60}$ Gerald Friesen, The Canadian Prairies, 141. See also Morris, The Treaties of Canada, 320-327.

${ }^{61}$ Ibid., 327

${ }^{62}$ Morris. The Treaties of Canada, 40

${ }^{63}$ The additional concessions that were granted to the Indian signatories of Treaty Six were agreed to by the government as they were not considered to run contrary to the government's goal of assimilating Indian culture. As will be seen, these concessions were in fact considered to help facilitate that goal.

${ }^{6}$ That these terms were introduced by the Indians is evident in the transcripts of the negotiations. For example. Morris implies as much when he states of the Treaty that "it is more than has been done anywhere else; I must do it on my own responsibility, and trust to the other Queen's councillors to ratify it." Morris, The Treaties of Canada, 215.

"Ibid., 354-355

“Ibid., 252

${ }^{67}$ Ibid., 354-355

${ }^{68}$ Ibid., 178

${ }^{69}$ George Brown and Ron Maguire, Indian Treaties in Historical Perspective, (Ottawa, 1979), 36

${ }^{70}$ Morris, The Treaties of Canada, 178

"Brown and Maguire. Indian Trenties, 38

"Sarah Carter has noted that there were many problem attached to farming in the North-West. "Crops were often damaged by frost and scourged by squirrels, gophers, and dogs. Grasshopper plagues occurred almost annually." Carter, Lost Harvests, 42.

"Erasmus, Buffalo Days and Nights, 252. Dickason makes note of the English spelling of Big Child's true Indian name. Mistawasis, in Canada's First Nations, 300. Similarly, Alexander Morris noted the spelling of Big Child's name as Mis-tah-wah-sis in Morris, The Treaties of Connda. 213.

"Ibid., 212

"Ibid., 204-212 